\title{
Phytochemical and Antifungal Activity of Leaf Extracts of Prosopis africana and Anacardium occidentale against Macrophomina Root Rot of Sesamum indicum L. in Benue State, Central Nigeria
}

\author{
Matthew Elaigwu1, Hyacinth Ocheigwu Apeh Oluma², Amana Onekutu² \\ ${ }^{1}$ Department of Integrated Science, College of Education, Oju, Benue State, Nigeria \\ ${ }^{2}$ Department of Biological Sciences, University of Agriculture Makurdi, Benue State, Nigeria \\ Email: Elaigwumatthew1986@gmail.com
}

How to cite this paper: Elaigwu, M., Oluma, H.O.A. and Onekutu, A. (2018) Phytochemical and Antifungal Activity of Leaf Extracts of Prosopis africana and Anacardium occidentale against Macrophomina Root Rot of Sesamum indicum L. in Benue State, Central Nigeria. Journal of Geoscience and Environment Protection, 6, 66-76.

https://doi.org/10.4236/gep.2018.67005

Received: March 31, 2018

Accepted: July 16, 2018

Published: July 19, 2018

Copyright (c) 2018 by authors and Scientific Research Publishing Inc. This work is licensed under the Creative Commons Attribution International License (CC BY 4.0).

http://creativecommons.org/licenses/by/4.0/

\begin{abstract}
This study investigated the antifungal activity of leaf extracts of Prosopis africana and Anacardium occidentale against Macrophomina phaseolina, the causal agent of root rot of Sesamum indicum L. Phytochemical analysis of the two plants showed the presence of alkaloids, saponins, tannins, flavonoids and anthraquinones in petroleum ether, ethyl acetate, methanol and water extracts. The effectiveness of the two medicinal plants viz: $P$. africana and $A$. occidentale was tested against the causative agent of root rot of Sesamum indicum L. The effect of plant leaf extracts on mycelia growth of the test organism shows that both $P$. africana and $A$. anacardium reduced the mycelia growth significantly as compared to the control (plate, 2, 3, 4). The antifungal property of $P$. africana and $A$. occidentale makes these plants of potential interest for the control of the fungi Macrophomina phaseolina.
\end{abstract}

\section{Keywords}

Phytochemical, Antifungal Screening, Prosopis africana, Anacardium occidentale, Leaf Extracts, Macrophomina Phaseolina (Tassi) Goid

\section{Introduction}

Plants have long served mankind as source of medicinal agents. These have been found to possess fungicidal properties against various phytopathogenic fungi [1]. Elaigwu, et al. [2] earlier reported that the extracts of Prosopis. africana and 
Anacardium occidentale significantly reduced the incidence on the development of $M$. phaseolina root rot disease both in pre-yield and yield parameters. Similarly, the extracts of pulverized bark of Prosopis africana and leaves of $N$. latifolia inhibited both radial mycelia growth and sclerotial formation of Macrophomina phaseolina by $100 \%$ [3] .

Akash [4] reported that petroleum ether extract and ethanolic extracts of Anacardium occidentale leaves exhibited significant antimicrobial and antifungal activity. Similarly, Ezike [5] reported that almost all parts of Prosopis africana tree are used in medicine; the leaves in particular are used for the treatment of headache and toothache as well as various other head ailments. Leaves and bark are combined to treat rheumatism. Remedies for skin diseases, caries, fevers and eyewashes are obtained from the bark. The roots are a diuretic and are used to treat gonorrhea, tooth and stomach-ache, dysentery and bronchitis. In Mali, the leaves, bark, twigs and roots are used to treat and relieve bronchitis, dermatitis, tooth decay, dysentery, malaria and stomach cramps. In Ghana, boiled roots serve as a poultice for sore throat, root decoction for toothache, and bark as a dressing or lotion for wounds or cuts. In Ghana, the pod ashes of $P$. africana are source of potash for soap making [5].

The fruits or seeds of the cashew are consumed whole, roasted, shelled and salted, in Madeira wine, or mixed in chocolates. Bark is used in tanning. Stems exude a clear gum used in pharmaceuticals and as substitute for gum Arabic. Juice turns black on exposure to air and provides an indelible ink [6].

Among the fungi diseases, the root rot caused by $M$. phaseolina remains to be a challenging task in terms of management, since it is soil borne in nature. Many synthetic fungicides have shown promise in the control of Sesame disease [7]; however, the high cost of such chemicals forbids their use by poor resource farmers. Furthermore, continuous use of these chemicals may pose serious health hazards to the applicator as well as to consumer of the treated material as toxic forms persist in soil and contaminate the whole environment besides from development of resistant strains [8].

These facts necessitate the search for alternatives in plant products that are environmentally friendly, many of which have been reported in the control of several plant diseases [2] [9] [10].

\section{Materials and Methods}

\subsection{Collection and Identification of Plant Materials}

Fresh leaves of Prosopis africana and Anacardium occidentale were collected from the premises of Federal University of agriculture Makurdi, Nigeria in March, 2012. Taxonomic identification of the plant samples were authenticated at the Department of Biological Sciences University of agriculture Makurdi. Voucher specimens were preserved in the Herbarium collection of the Department of Biological Sciences, University of Agriculture, Makurdi. 


\subsection{Isolation of the Fungi Pathogen}

The pathogen, Macrophomina phaseolina (Tassi) Goid used for this experiment was isolated according to the method of Oluma \& Elaigwu [3] and confirmed by (International Mycological Institute (IMI), Kew Survey, England.

\subsection{Preparation of Czapeck-Dox-Agar Medium (CDA)}

The Czapeck-dox-agar medium (CDA) comprised of the following; Sodium nitrate $\left(\mathrm{NaNO}_{3}\right) 3.0 \mathrm{gm}$, Ferrous sulphate $\left(\mathrm{FeSO}_{4} \cdot 7 \mathrm{H}_{2} 0\right) 0.01 \mathrm{gm}$, Di-potassium hydrogen orthophosphate $\left(\mathrm{K}_{2} \mathrm{HpO}_{4}\right) 1 \mathrm{gm}$, Magnesium sulphate $\left(\mathrm{MgSO}_{4} \cdot 7 \mathrm{H}_{2} 0\right) 0.5$ gm, Potassium chloride (Kcl) $0.01 \mathrm{gm}, 20 \mathrm{gm}$ each of glucose and plain agar and sterile distilled water $1000 \mathrm{~cm}^{3}$ and autoclaved at 15 p.s.i. $\left(121^{\circ} \mathrm{C}\right.$ for $15 \mathrm{mi}-$ nutes).

\subsection{Preparation of Pure Culture}

Pure cultures of the pathogens were obtained by sub-culturing colonies growing from the plated root tissues on Czapecks agar (CDA) medium.

\subsection{Inoculation of the Test Organism}

To study the effect of plant extracts on the growth and sporulation of the fungus, the CDA-plant extracts was inoculated respectively at the centre of the plates with $2 \mathrm{~mm}$ mycelia discs of the test fungus. The mycelia plugs were obtained with $2 \mathrm{~mm}$ cork borer lifted from the margin of actively growing culture of the test fungi. These were placed upside down in centre of each plate. The inoculated plates were incubated at $28^{\circ} \mathrm{C} \pm 2^{\circ} \mathrm{C}$ for 6 days. Plates of medium without plant extracts served as control.

\subsection{Effect of Plant Extracts on Mycelium Growth}

The poisoned food method was used in the preliminary screening of aqueous extracts for their antifungal properties evaluation. First, the mycelia growths were evaluated in $60 \mathrm{~mm}$ Petri dishes filled with CDA solid medium amended with $20 \%$ aqueous extracts of each plant. Next, the center of each Petri dish was inoculated with $5 \mathrm{~mm}$ diameter disc of fungal mycelium, taken from pure culture ( 7 days old). The petridish without plant extract served as control. Then, all inoculated dishes were incubated at $25^{\circ} \mathrm{C}$ for 6 days (plate $1,2,3,4$ ).

\subsection{Extraction of Plant Materials}

The two plant materials (leaves of $A$. occidentale and $P$. africana) were sun-dried for 2 weeks, after which it was ground to a uniform powder.

\subsection{Petroleum Ether Extraction}

Two hundred g each of Anarcadium occidentale and Prosopis africana were separately extracted with petroleum ether in $450 \mathrm{ml}$. Each of the plant material 
was dissolved in $450 \mathrm{ml}$ of the solvent in a sterile conical flask at room temperature for 24 hours. The conical flask was covered with cotton wool, wrapped with aluminium foil. The extracts were filtered after 24 hours, first through cheese cloth and then through a Whatmann filter paper No. $42(125 \mathrm{~mm})$. The dark brownish, light brown and brownish filtrate were obtained and transferred into a labeled specimen bottle. The powdered plant materials was removed and spread on the laboratory bench to dry for two weeks.

This experiment was similarly performed for ethyl acetate and methanol extraction (Table 1).

\subsection{Water Extraction}

The specimens were washed with several changes of sterile distilled water and were later pulverized using pestle and mortar according to the method of [11]. The crushed leaves were separately plunged in required quantity of water (1:1 $\mathrm{w} / \mathrm{v}$ ) in a beaker and boiled at $100^{\circ} \mathrm{C}$ for 10 minutes. Crude extracts of the leaves were obtained after 24 hours in the laboratory at $28^{\circ} \mathrm{C} \pm 2{ }^{\circ} \mathrm{C}$ by filtering the infusions through cheese cloth and then through a Whatmann filter paper No. 42 $(125 \mathrm{~mm})$ which formed a standard plant extracts $(100 \%)$.

\section{Phytochemical Screening of the Leaf Extracts}

Phytochemical screenings were performed using standard procedures [12] [13] with petroleum ether, ethyl acetate, methanol and aqueous leaf extract for both Prosopis africana and Anarcadium occidentale extract as shown in Table 1.

Table 1. Petroleum ether extract of Prosopis africana (leaves).

\begin{tabular}{|c|c|c|c|}
\hline S/NO & TEST & OBSERVATION & INFERENCE \\
\hline 1 & $\begin{array}{c}\text { Draggen dorff's and Mayer's } \\
\text { reagents }\end{array}$ & No turbidity or precipitation & Alkaloids absent \\
\hline 2 & Frothing test & $\begin{array}{l}\text { Frothing did not persist on } \\
\text { warming }\end{array}$ & Saponins absent \\
\hline 3 & Ferric chloride reagent test & $\begin{array}{l}\text { No blue-green precipitate } \\
\text { formed }\end{array}$ & Tannins absent \\
\hline 4 & $\begin{array}{l}\text { Dil. Ammonia and conc. } \\
\qquad \mathrm{H}_{2} \mathrm{So}_{4} \text { test }\end{array}$ & $\begin{array}{l}\text { No yellow colouration formed on } \\
\text { standing }\end{array}$ & Flavonoids absent \\
\hline 5. & $\begin{array}{c}\mathrm{H}_{2} \mathrm{SO}_{4} \text {, chloroform and } \\
\text { Ammonia test }\end{array}$ & $\begin{array}{l}\text { The resulting solution changes } \\
\text { from brown to colourless }\end{array}$ & $\begin{array}{c}\text { Anthraquinones } \\
\text { present }\end{array}$ \\
\hline
\end{tabular}

\section{Results}

Table 2. Phytochemical screening of PEE, EAE, MEE and ALEfor P.africana extracts (leaves).

\begin{tabular}{ccccccc}
\hline S/NO & Test & Reagent & PEE & EAE & MEE & AWE \\
\hline 1 & Alkaloids & $\begin{array}{c}\text { Dragendorff } \\
\text { and Mayer's Reagents }\end{array}$ & - & + & + & + \\
\hline
\end{tabular}




\begin{tabular}{|c|c|c|c|c|c|c|}
\hline \multicolumn{7}{|c|}{ Continued } \\
\hline 2 & Saponins & $\begin{array}{c}\mathrm{NaHCO}_{3 \mathrm{aq}} \\
\text { Emulsion foaming test. }\end{array}$ & - & + & + & + \\
\hline 3 & Tannins & $5 \% \mathrm{FeCl}_{3 \mathrm{aq}} 10 \% \mathrm{KOH}_{\mathrm{aq}}$ & - & + & + & - \\
\hline 4 & Flavonoids & $\begin{array}{l}\text { Dil. Ammonia and } \\
\text { conc. } \mathrm{H}_{2} \mathrm{SO}_{4}\end{array}$ & - & - & + & + \\
\hline 5 & Anthraquinones & $\begin{array}{c}\mathrm{H}_{2} \mathrm{SO}_{4} \text {, Chloroform and } \\
\text { Ammonia }\end{array}$ & + & - & + & - \\
\hline
\end{tabular}

Table 3. Phytochemical screening of PEE, EAE, MEE and ALE for Anarcadium occidentale extracts (leaves).

\begin{tabular}{|c|c|c|c|c|c|c|}
\hline $\mathrm{S} / \mathrm{NO}$ & Test & Reagent & PEE & EAE & MEE & AWE \\
\hline 1 & Alkaloid & $\begin{array}{c}\text { Dragendorffs and Mayer's } \\
\text { Reagents }\end{array}$ & - & + & + & - \\
\hline 2 & Saponins & $\begin{array}{c}\mathrm{NaHCO}_{3 \mathrm{aq}} \text { Emulsion foaming } \\
\text { test }\end{array}$ & - & + & + & - \\
\hline 3 & Tannins & $5 \% \mathrm{FeCl}_{3 \mathrm{aq}}$ and $10 \% \mathrm{KOH}_{\mathrm{aq}}$ & - & - & + & + \\
\hline 4 & Flavonoids & Dil. Ammonia andconc. $\mathrm{H}_{2} \mathrm{SO}_{4}$ & - & + & + & + \\
\hline 5 & Anthraquinones & $\begin{array}{c}\mathrm{H}_{2} \mathrm{SO}_{4} \text {, Chloroform and } \\
\text { Ammonia }\end{array}$ & + & - & + & + \\
\hline
\end{tabular}

Legend: $+=$ positive. $-=$ negative. $\mathrm{PEE}=$ Petroleum ether extract. $\mathrm{EAE}=$ Ethyl acetate extract. $\mathrm{MEE}=\mathrm{Me}-$ thanol extract. ALE $=$ Aqueous Leaf extract.

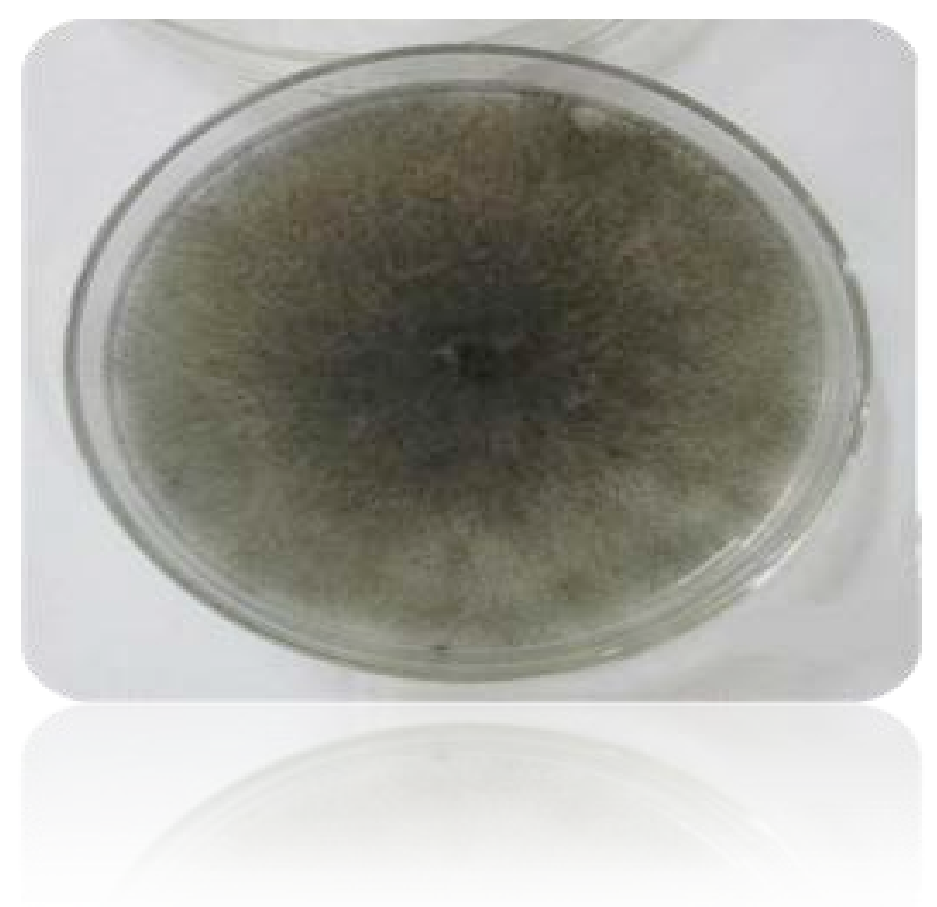

Figure 1. A pure culture of the test organism (Macrophomina phaseolina). 


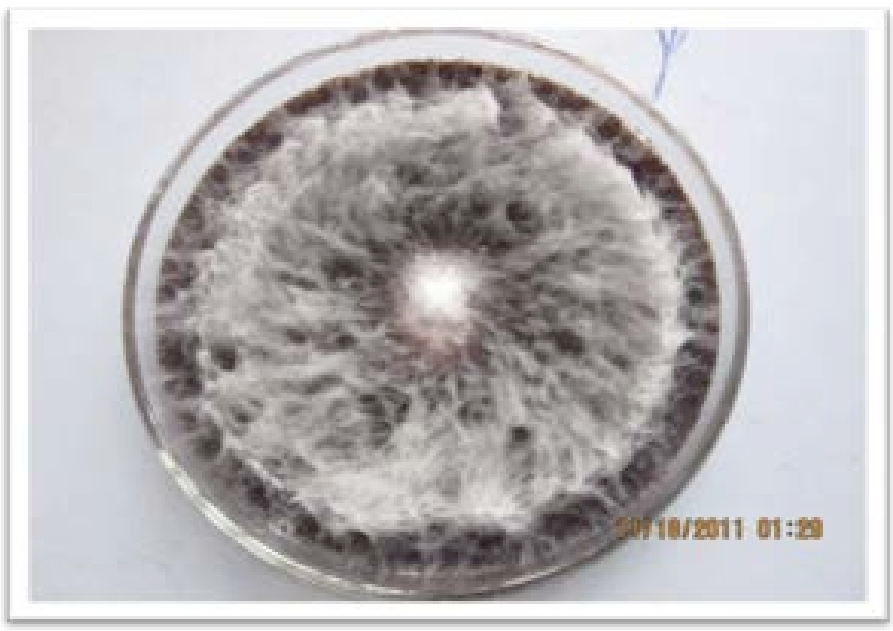

Figure 2. Control experiment.

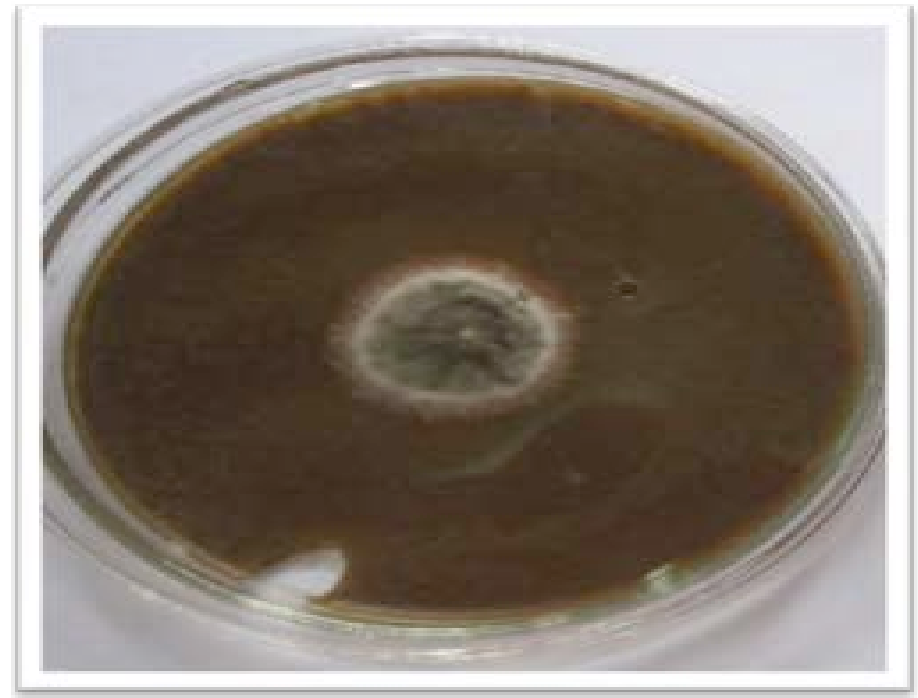

Figure 3. Prosopis africana.

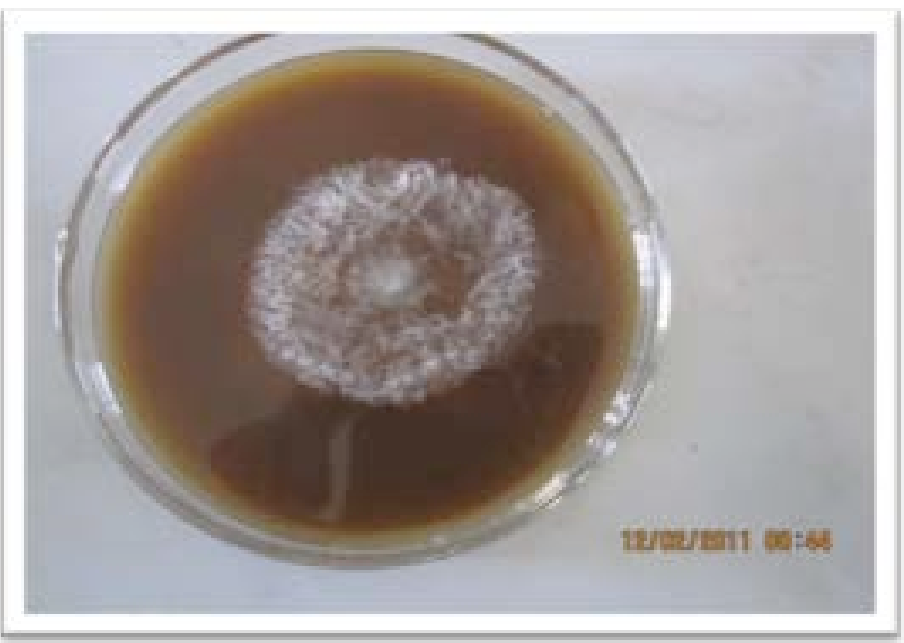

Figure 4. Anacardium occidentale. 


\section{Discussion}

The study has demonstrated the antifungal activity of Prosopis africana and Anarcadium occidentale against Macrophomina phaseolina. This indicates their broad range of activity. These results agree with those reported by Elaigwu et al. [2] that extracts of $P$. africana and $A$. occidentale significantly reduced the incidence on the development of $M$. Phaseolina root rot disease both in pre-yield and yield parameters. This is consistent with the earlier reports that many plant products contain fungitoxic constituents that have the potential to control plant diseases [9] [14] [15]. Apart from this indication of antifungal activity here, in Nigeria, the decoction of root and stem of Anacardium occidentale has been used as anti -inflammatory agent and anti-diarrhoea [16]. Similarly, the antimicrobial activities of Anacardium occidentale extracts have been confirmed [17] [18]. Omojasola and Awe [19] observed the antimicrobial activity of the leaf of Anacardium occidentale and Gossypium hirsutum against Escherichia coli, Shigella dysenteriae, Salmonella typimurium, Staphylococcus aureus and pseudomonas aeruginosa. The phytochemical analysis of the two plants extracts indicated that alkaloids, saponins, tannins, flavonoids and anthraquinones were detected in various components of plant products. For instance, Lale [20] reported that the bioactivity of plant products was related to the chemical nature of their active constituents, such as alkaloids, saponins, tannins, flavonoids and glycoside. These finding confirms the work of Tewari \& Singh [21] that the valuable medicinal properties of different plants are due to presence of several constituents i.e. saponines, tannins, alkaloids, alkenyl phenols, glycol alkaloids, flavonoids, sesquiterpenes lactones, terpenoids and phorbol esters. The presence of high amount of tannins and moderate saponins in Anacardium occidentale agrees with the report of Okorie et al. [22]. The methanolic extracts of both plants show the presence of all the active ingredients. This might be due to the ability of the solvent to extract more of the active ingredients (bioactive compounds) from the plant materials. This is similar to the findings of Arekemase et al. [23] that the high potency of ethanol extracts might be connected with the extraction solvent and that ethanol has been shown to have a greater extractive power than water.

The presence of flavonoids in methanolic extract of Anarcadium occidentale agrees with the earlier work of [24] that the ethanolic extract of cashew nuts revealed the presence of phytochemical compounds such as triterpenoids, phenolic, flavonoids, xanthoproptein and carbohydrate. The extracts obtained from the flowers, leaves and stem bark of Anacardium occidentale are rich in bioactive secondary metabolities, exerting a potential antimicrobial effects against Gram-positive and Gram-negative bacteria as well as fungi [25]. Similarly, it was also observed that $A$. occidentale has important biotechnological potential as a source of compounds with broad-spectrum antimicrobial activity and of antioxidant compounds to be used in the drug, food and cosmetic industry [25]. The chemical analysis of Prosopis africana is confirmed to contain alkaloids, be- 
ta-phenethylamine (https://www.ncbi.nlm.nih.gov/pubmed/10904169) and tryptamine [26]. It was confirmed that phytochemical screening of Prosopis africana revealed the presence of tannins, saponins, anthraquinones, cardiac-glycosides, carbohydrate and steroids, these extracts showed antihelmminthic activity against the disease schistosomiasis [27]. Similarly, Badamasi [28] confirmed that phytochemical screening of the stem bark extract of Prosopis africana revealed the presence of alkaloids, tannins, glycosides,cardiac glycosides, saponin, volatile oil and steroids had anti-malaria potentials. Arshad \& Rehman, [29] reported that a significant reduction in fungal biomass was recorded due to different concentrations of the leaf extracts of E. citrodora and that organic solvent extracts of allelopathatic especially chloroform contain antifungal constituents and can effectively be used for the management of $M$. phaseolina. Similarly, Jabeen [30] observed the fungal activity of alcoholic and chloroform extracts of leaves of E. citriodora against $A$. rabiei. Prince and prabakaran [31], demonstrated that Vitex negundo showed maximum antifungal activity against the pathogenic fungus Colletotrichum falcatum.

According to Shadab [32] Cymbopogon citratus (Lemon grass) oil is used as a pesticide

(http://www.pjsir.org/documents/journals/01042011130700_PJSIR-VOL.35-(6)1992-Abstract.pdf) and as preservative. Kareru [33] reported that Thevetia peruviana contains a milky sap containing a compound called thevetin (http://www.academicjournals.org/article/article1380870360_Kareru\%20et\%20al .pdf) in its natural form is extremely poisonous, as well as all parts of the plants, especially the seeds. Similarly, Ogunbosoye \& Babayemi [34] confirmed that the leaves of Newbouldia leavis have antibiotic, bacteristatic and fungistatic properties. Arshad \& Rehmen, [29] observed that the leaf extracts of allelopathatic trees especially ethyl acetate and chloroform extracts of $A$. indica contain natural fungicides which can be used for the management of $M$. phaseolina. Tannins isolated from medicinal plants possess remarkable toxic activity against bacteria and fungi and may assume pharmacological importance in future [35].

Further studies are, however, necessary to determine the minimum concentration of the extracts required for maximum disease control as well as the frequency and mode of application of the different plant extracts. Investigations into the active ingredients of the extracts and the mode of action are also necessary.

\section{Conclusion}

The effect of plant extracts on mycelia growth of the test organism shows that both $A$. africana and $A$. anacardium reduced the mycelia growth drastically as compared to the control (plate, 2, 3, 4). The phytochemical analysis of the plant extracts shows alkaloids, saponins products, tannins, flavonoids and anthraquinones. The activities of these antioxidants in the plant extracts probably contri- 
bute to the effectiveness of these extracts and could be possible to be exploited for effective management of root rot diseases of Beniseed (Sesamum indicum) caused by Macrophomina phaseolina.

\section{References}

[1] Mohammad, D.H. and Merajul, I.R. (2015) In Vitro Studies on Phytochemical Screening of Different Leaf Extracts and Their Antifungal Activity against Seed Borne Pathogen Aspergillus niger. Journal of Plant Pathology \& Microbiology, 6, 320.

[2] Elaigwu, M., Oluma, H.A.O. and Ochokwunu, D. (2017) In Vivo and In Vitro Activities of Some Plant Extracts on Macrophomina Phaseolina (Tassi) Goid. The Casual Agent of Charcoal Rot of Sesame in Benue State, Nigeria. IJSRM, 5, No. 4.

[3] Oluma, H.O.A. and Elaigwu, M. (2006) Antifungal Activity of Extracts of Some Medicinal Plants against Macrophomina phaseolina (Tassi). Goid. Nigeria Journal of Botany, 19, 121-128.

[4] Akash, P.D., Vishal, D.J. and Arun, B.J. (2009) Antimicrobial Screening of Different Extract of Anacardium occidentale Linn. Leaves. Journal of Chem Tech Research, 1, 856-858.

[5] Ezike, A.C., Akah, P.A., Okoli, C.O., Udegbunam, S., Okwume, N., Okeke, C. and Iloani, O. (2010) Medicinal Plants Used in Wound Care: A Study of Prosopis africana (Fabaceae) Stem Bark. Indian Journal of Pharmaceutical Sciences, 72, 3349 p.

[6] Patro, C. and Behera, R.N. (1979) Cashew Helps to Fix sand Dunes in Orissa. Indian Farming, 28, 31-32.

[7] Shokalu, O., Enikuomehin O.A., Idowu, A.A. and Uwala, A.C. (2002) Effects of Seed Treatment on the Control of Leaf Blight Disease of Sesame. Tropical Oilseeds Journal, 7, 94-100.

[8] Hayes, W.J. and Laws, E.R. (1991) Handbook of Pesticide Toxicology. Academic Press Inc., New Delhi, 25-30.

[9] Enikuomehin, O.A. and Peters, O.T. (2002) Evaluation of Crude Extracts from Some Nigerian Plants for the Control of Field Diseases of Sesame (Sesamum indicum L.). Tropical Oilseeds Journal, 7, 84-93.

[10] Okigbo, R.N. and Emoghene, A.O. (2003) Effect of Leaf Extract of Three Plant Species on Mycosphaerella fijiensis Morelet, the Causal Organism of Black Sigatoka Disease of Banana (Musa acuminata). Nigerian Journal of Plant Protection, 20, 101-110.

[11] Oluma, H.O.A. and Garba, I.U. (2004). Screening of Eucalyptus globulus and Ocimum gratissimum against Pythium aphanidermatum. Nigeria Journal of Plant Protection, 21, 109-114.

[12] Sofowora, A. (1993) Medicinal Plants and Traditional Medicine in Africa. Spectrum Books Ltd., Ibadan.

[13] Trease, G.E. and Evans, W.C. (1989) Pharmacognosy: A Physician's Guide to Herbal Medicine. 13th Edition, Bailiere Tindall, London, 912.

[14] Tewari, S.N. and Nayak, M. (1999) Activity of Four Plant Extracts against Three Fungal Pathogens of Rice. Tropical Agriculture (Trinidad), 68, 373-375.

[15] Amadioha, A.C. and Obi, V.I. (1999) Control of Anthracnose Disease of Cowpea by Cympopogon citratus and Ocimum gratissimum. Acta Phytopathologica et Ento- 
mologica Hungarica, 34, 85-89.

[16] Mota, M.L., Thomas, G. and Barbosa-filho, J.M. (1985) Anti-Inflammatory Actions of Tannins Isolated from the Bark of Anacardium occidentale L. Journal of Ethnopharmacology, 13, 289-300. https://doi.org/10.1016/0378-8741(85)90074-1

[17] Laurens (1982) Study of Antimicrobial Activity of Anarcadiun occidentale. Annales Pharmaceutiques Françaises, 40, 143-146.

[18] Kudi, A.C., Umoh, J.U. and Eduve, L.E. (1999) Screening of Some Nigeria Medicinal Plants for Antibacterial Activity. Journal of Ethnopharmacology, 69, 225-228. https://doi.org/10.1016/S0378-8741(98)00214-1

[19] Omojasola, P.F. and Awe, S. (2004) The Antibacterial Activity of the Leaf Extracts of Anacardiun occidentale and Gossypium hirsutun against Some Selected Microorganisms. Bioscience Research Communications, 60, 25-58.

[20] Lale, N.E.S. (2002) Bio-Activity and Limitation against Wide Spread Use of Neem Products for the Management of Insect Pests. Nigerian Journal of Experimental and Applied Biology, 3, 115-125.

[21] Tewari, S. and Singh, A. (2004) Toxic and Sub Lethal Effects Oleadrin on Biochemical Parameters of Freshwater Air Breathing Murrel. Chant Punctatus (Bloch.). Indian Journal of Experimental Biology, 42, 413-418.

[22] Okorie, J.M., Okonkwo, T.J. and Okonta, N. (2010) Sub-Chronic Hepatoxicity of Anarcadium occidentale. Indian Journal of Pharmacology Science, 72, 353-357.

[23] Arekemase, M.O., Oyeyiola, G.P. and Aliyu, M.B. (2011) Antibacterial Activity of Anacardium occidentale on Some Enterotoxin Producing Bacteria. International Journal of Biology, 3, 92-97. https://doi.org/10.5539/ijb.v3n4p92

[24] Rajesh, K.V., Sumathi, C.S., Balasubramanian, V. and Ramesh, N. (2009) Elementary Chemical Profiling and Antifungal Properties of Cashew (Anacardium occidentale L.) Nuts. Botany Research International, 2, 253-257.

[25] Rubenice, A.S., Silvana, A.L., Flavia, M., Amaral, F.R., Fernandes, N., Luce, M.B., Valério, M.N. and Rosane, N.M.G. (2016) Antimicrobial and Antioxidant Activity of Anacardium occidentale L. Flowers in Comparison to Bark and Leaves Extracts. Journal of Biosciences and Medicines, 4, 87-99.

[26] Tapia, A., Egly, F.G., Bustos, D., Astudillo, L., Theoduloz, C. and Schmeda-Hirschmann, G. (2000) Biologically Active Alkaloids and a Free Radical Scavenger from Prosopis Species. Journal of Ethnopharmacology, 71, 241-246. https://doi.org/10.1016/S0378-8741(00)00171-9

[27] Rwang, P.G., Fabiyi, J.P., Suleiman, M. and Mercy, K.P. (2016) Evaluation and Phytochemical Analysis of Prosopis africana and Erythrina senegalensis Used against Immature Stages of Schistosoma haematobium. European Journal of Medicinal Plants, 13, 1-9. https://doi.org/10.9734/EJMP/2016/17675

[28] Badamasi, M.Z., Adamu, T.U., Abubakar, U., Ladan, M.J. and Bala, A.Y. (2011) Antimalarial Activity and Phytochemical Analysis of the Aqueous Stem Bark Extract of Prosopis africana (Kirya) against Plasmodium Species. Nigerian Journal of Parasitology, 32, 271-275.

[29] Arshad, J. and Rehman, H.A. (2011) Antifungal Activity of Leaf Extracts of Some Medicinal Trees against M. phaseolina. Journal of Medicinal Plants Research, 5, 2868-2872.

[30] Jabeen, K. and Javid, A. (2008) Antifungal Activity of Aqueous and Organic Solvent Extracts of Allelopathic Trees against Ascochyta rabiei. Allelopathy Journal, 22, 231-238. 
[31] Prince, L. and Prabakaran, P. (2011) Antifungal Activity of Medicinal Plants against Plant Pathogenic Fungus Colletotrichum falcatum. Asian Journal of Plant Science and Research, 1, 84-87.

[32] Shadab, Q., Hanif, M. and Chaudhary, F.M. (1992) Antifungal Activity by Lemongrass Essential Oils. Pakistan Journal of Scientific and Industrial Research, 35, 246-249.

[33] Kareru, P.G., Keriko, J.M., Kenji, G.M. and Gachanja, A.N. (2010) Anti-Termite and Antimicrobial Properties of Paint Made from Thevetia peruviana (Pers.) Schum. Oil Extract. African Journal of Pharmacy and Pharmacology, 4, 87-89.

[34] Ogunbosoye, D.O. and Babayemi, O.J. (2010) Potential Values of Some Non-Leguminous Browse Plants as Dry Season Feed for Ruminants in Nigeria. African Journal of Biotechnology, 9, 2720-2726.

[35] Banso, A. and Adeyemo, S.O. (2007) Evaluation of Antimicrobial Properties of Tannins Isolated from Dichrostachys cinereaa. African Journal of Biotechnology, 6, 1785-1787. https://doi.org/10.5897/AJB2007.000-2262 